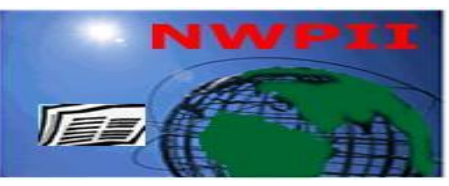

American Journal of Biomedical Sciences

ISSN: 1937-9080

nwpii.com/ajbms

\title{
Hepatitis B Vireamia in Hepatitis B Surface Antigenemic Patients in Bangladesh
}

\author{
Fazley Rabbi Sha ${ }^{1}$, M Moyen Uddin PK $^{2 *}$, Mohammad Khairul Islam Sarkar ${ }^{3}$, Rabiul Islam \\ Talukder $^{2}$, Abdul Hai Siddique ${ }^{4}$, Kamrun Nahar ${ }^{5}$, Muhammad Saiedullah ${ }^{6}$, Yearul Kabir ${ }^{7}$ \\ ${ }^{1}$ Rajshahi University, Rajshahi 6205, Bangladesh \\ ${ }^{2}$ Primeasia University, Dhaka 1213, Bangladesh \\ ${ }^{3}$ Independent University, Bangladesh (IUB) \\ ${ }^{4}$ Tohoku University, Sendai, Miyagi Prefecture 980-8577, Japan \\ ${ }^{5}$ Dhaka Medical College Hospital, Dhaka 1000, Bangladesh \\ ${ }^{6}$ University of Health Sciences, Dhaka 1216, Bangladesh \\ ${ }^{7}$ University of Dhaka, Dhaka 1000, Bangladesh \\ *Corresponding Author \\ M Moyen Uddin PK \\ Department of Biochemistry \\ Primeasia University \\ Rd No 17 \\ Dhaka 1213, Bangladesh \\ Email: moyen.uddinpk@ primeasia.edu.bd
}

Received: 20 June 2016; | Revised: 21 November 2016; | Accepted: 7 December 2016

\begin{abstract}
Objectives: This study evaluates the distribution of hepatitis B vireamia in patients with hepatitis B virus (HBV) infection. Methods: HBV-infected patients were enrolled in this study. HBV DNA tests were carried out using Smart Cycler II to detect HBV DNA level in serum samples of all HBsAg-positive patients. Results: The distribution of HBV DNA level was found significantly related to age groups $(p<0.05)$, gender group ( $\mathrm{p}<0.05)$, ALT group ( $<<0.05)$, and HBeAg group $(\mathrm{p}<0.05)$. The HBV DNA level was recorded to be significantly higher in the HBeAg-positive group $(p<0.05)$ in compared to the HBeAg-negative group. Conclusions: A low level of viral replication may persevere in chronic $\mathrm{HBV}$-infected patients who are HBeAg-negative, and the level of HBV DNA was higher in the HBeAg-positive group.
\end{abstract}

Keywords: Hepatitis B, HBV DNA level, HBeAg, ALT

\section{Introduction}

The hepatitis B virus (HBV) is one of several viruses known to cause hepatitis in humans. Until the 1970s, laboratory tests were not available to distinguish any of these clinically similar infections. HBV is completely unrelated to the viruses that cause hepatitis $\mathrm{A}, \mathrm{C}$, or other non-A, non-B (NANB) hepatitis [1]. 
HBV is usually transmitted by contact with the blood, semen or vaginal secretions of an infected (HBV DNA or HBsAg-positive) person. Because of the high concentration of virus in blood, an extremely small inoculum is sufficient to transmit infection. The virus must be introduced through broken skin or come into contact with mucous membranes for infection to occur. HBV may also be found in saliva and other body fluids [2].

HBV transmission patterns and the seroprevalence of chronic HBV infection vary markedly worldwide, although seroprevalence studies in many countries are limited, and the epidemiology of hepatitis $\mathrm{B}$ is changing. Approximately $45 \%$ of persons worldwide live in regions in which $\mathrm{HBV}$ is highly endemic (i.e., where prevalence of chronic HBV infection is $\geq 8 \%$ among adults and that of resolved or chronic infection [i.e., anti-HBc positivity] is $>60 \%$ ) [3]. Historically, $>90 \%$ of new infections occurred among infants and young children as the result of perinatal or household transmission during early childhood [4]. Infant immunization programs in many countries have led to marked decreases in incidence and prevalence among younger, vaccinated members of these populations. Countries of intermediate HBV endemicity (i.e., HBsAg prevalence of $2 \%-7 \%$ ) account for approximately $43 \%$ of the world's population; in these countries, multiple modes of transmission (i.e., perinatal, household, sexual, injection-drug use, and health-care--related) contribute to the infection burden. Regions of the world with high or intermediate prevalence of $\mathrm{HBsAg}$ include much of Eastern Europe, Asia, Africa, the Middle East, and the Pacific Islands [3, 5]. In countries of low endemicity (i.e., HBsAg prevalence of $<2 \%$ ), the majority of new infections occur among adolescents and adults and are attributable to sexual and injection-drug-use exposures. However, in certain areas of low HBV endemicity, prevalence of chronic HBV infection is high among indigenous populations born before routine infant immunizations.

Hepatitis B virus (HBV) infection is one of the major causes of chronic liver diseases in the world and also in Bangladesh. HBV causes a broad spectrum of liver diseases ranging from acute self-limited hepatitis to fulminant hepatitis, chronic hepatitis, and asymptomatic infection. It is also one of the main causes of liver cirrhosis and hepatocellular carcinoma (HCC) [69]. Infection with hepatitis $B$ virus (HBV) is a major public health problem, affecting about 350400 million people worldwide. It is endemic in Asia, sub-Saharan Africa, the South Pacific Region, Australia, and New Zealand and in some populations of South America and the Middle East $[10,11]$. There are well-known geographical differences in the prevalence of HBV infection. By virtue of its morbidity and mortality HBV infection is of definite concern in the East (AsiaPacific region) where it reflects an important public health problem. The progressive of chronic HBV infection vary significantly between the East (prevalence $>10 \%$ ) and the West (prevalence $<1 \%$ ) [12]. The prevalence of HBV infection ranges from 2 to $8 \%$, in the South Asian region according to the report of World Health Organization. As per WHO Bangladesh in the ranked of moderate to high risk group of countries for HBV infection in 2001 [13]. The evolution of chronic hepatitis B completely depends upon the geographic location of the host, age and mode of acquisition of virus and predominant type of virus. In high endemic regions perinatal infection or horizontal infection early in childhood are the main routes of HBV transmission, whereas hepatitis $\mathrm{B}$ is primarily a disease of adolescents and adults as a result of high risk sexual activity and injection drug use [14]. In low endemic areas, such as Western countries, The possibility of becoming chronically infected is higher in individuals infected perinatally $(90 \%)$ or during childhood (20-30\%) when considering standing before an immature immune system comparing to immunocompetent individuals infected in adulthood $(<1 \%)$ [10,14]. Between 15 and $40 \%$ of chronically infected individuals may develop severe liver disease and hepatocellular carcinoma (HCC), while the remaining become inactive carriers [10]. During acute phase almost all the infants and most adults who progress to chronic infection have no symptoms. So, diagnosis largely depends on laboratory investigations. Routine hepatitis B serology includes tests for the 
detection of HBsAg, $\mathrm{HBeAg}$, their corresponding antibodies anti-HBs, anti-HBe and anti-HBc (total) and anti-HBcIgM. Subsequent infection with $\mathrm{HBV}$, characteristically $\mathrm{HBsAg}$ becomes detectable in serum during the incubation period of 3-5 weeks before emergence of clinical symptoms and after elevation of transaminase level it persists for 2-4 weeks. As the patient recovers it disappears in 2-6 months and after a window period, protective anti-HBs antibody appears.After acute infection the existence of HBsAg beyond six months is accepted as evidence of chronic infection [15].

$\mathrm{HBeAg}$ persist detectable for many months and usually for years in chronic hepatitis B virus infection. Detection of $\mathrm{HBeAg}$ has modest value in typical cases of acute hepatitis. In acute infection $\mathrm{HBe} A g$ generally becomes detectable in the serum when HBsAg first appears but disappears after several weeks when acute hepatitis resolves. On the other hand, $\mathrm{HBeAg}$ is an essential marker of viral replication, infectivity and ongoing liver injury in chronic infection. The presence of anti-HBe is associated with likelihood of spontaneous resolution of acute infection and the Antibody to $\mathrm{HBeAg}$ is detectable as HBeAg disappears from the serum. In chronic hepatitis $B$ virus infection the loss of $\mathrm{HBeAg}$ and attainment of anti-HBe tends to be associated with biochemical and histological enhancement [16].

For defining the grade of infectivity the clinicians still depend on patients $\mathrm{HBe} \mathrm{Ag} / \mathrm{Anti}$ $\mathrm{HBe}$ status and liver enzymes especially alanine aminotransferase (ALT) [17]. ALT flares reflect a high level of virus replication in chronic HBV carriers if they coincide with related clinical, biochemical, serological and histological alterations[18].

During acute phase of infection, anti-HBc of IgM class predominates. Within six months as the infection evolves anti-HBc IgM levels gradually decline and often become undetectable [19].

The detection of HBV DNA and HBV DNA polymerase gives a measure of active viral replication in plasma and is important in detecting HBV infection in sero-negative cases with viremia infected with mutant virus. The value of HBV DNA and HBV DNA polymerase is important in the selection of cases for treatment and in monitoring response to treatment. Currently available methods for detection of HBV DNA are direct hybridization or competitive polymerase chain reaction which is not routinely practiced in most hepatitis testing laboratories [20, 21]. The presence of $\mathrm{HBeAg}$ is accepted as a classical indicator of replication, it has been shown that in many populations, especially in Mediterranean region, anti-HBe and HBV DNA can be found positive together at the same time $[22,23,24]$. In a similar fashion, another point mutation at region 1897 induce development of another stop codon (TGA), or the transformation of start codon ATG into ACG hamper the translation of precore region [25]. Finally, during the natural course of $\mathrm{HBV}$ infection, the synthesis of $\mathrm{HBeAg}$ is interrupted during viral replication as a result of different mutations and only HBV DNA remains as a marker of viremia accompanied with anti-HBe [26].

\section{Materials and methods}

Blood samples were collected aseptically from $538 \mathrm{HBsAg}$ positive patients prescribed for diagnosis of HBV infection in Private Diagnostic Centre Ltd, Bangladesh. Samples were analyzed to determine the levels of some biochemical parameters including bilirubin, alanine aminotransferase (ALT) and aspartate aminotransferase (AST); and to determine the presence of some immunological parameters including $\mathrm{HBsAg}$, HBeAgand Anti-HBe. Dry Biochemistry Random Access Multibatch Analyzer (Vitros 350, J\&J, USA) and Vitros TBIL, ALT and AST slides were used to determine total serumbilirubin, ALT and AST levels, consecutively. All the experiments were carried out according to the manufacturer's instruction ( $\mathrm{J} \& \mathrm{~J}, \mathrm{USA}$ ).

To assess the immunological parameters, Multi Batch Immunoassay Analyzer (ARCHITECT i2000SR, Abbott, USA) was used for qualitative determination of $\mathrm{HBsAg}, \mathrm{HBeAg}$ and anti-HBeAg.

HBV DNA tests were carried out using molecular probe hybridization method (Digene 
hybrid capture system) to detect HBV DNA level in serum samples of all HBsAg-positive patients. In probe hybridization method, DNA value $>300$ virus copies/ml was considered as detectable DNA level in all serum samples.

The HBV DNA level was compared with $\mathrm{HBeAg} /$ anti-HBe status and the level of liver enzyme ALT. In this cross sectional study, data analysis was done by using SPSS (Statistical Package of Social Sciences).

\section{Results and discussion}

In this study, 538 hepatitis B surface antigenemic patients were recruited and evaluated for serological and biochemical profile of patients. The patients' age ranged from $10-65$ years with a mean of about 33.05 years. $28.1 \%$ the total (i.e. 151 patients) were found in $<25 y$ group followed by $\geq 41 \mathrm{y}(24.3 \%$ of the total, i.e. 131 patients), $25-30 y$ ( $19.7 \%$ of the total, i.e. 106 patients), $31-35 y$ ( $17.7 \%$ of the total, i.e. 95 patients), and $36-40 y$ ( $10.2 \%$ of the total, i.e. 55 patients) groups respectively, as shown in figure 1.

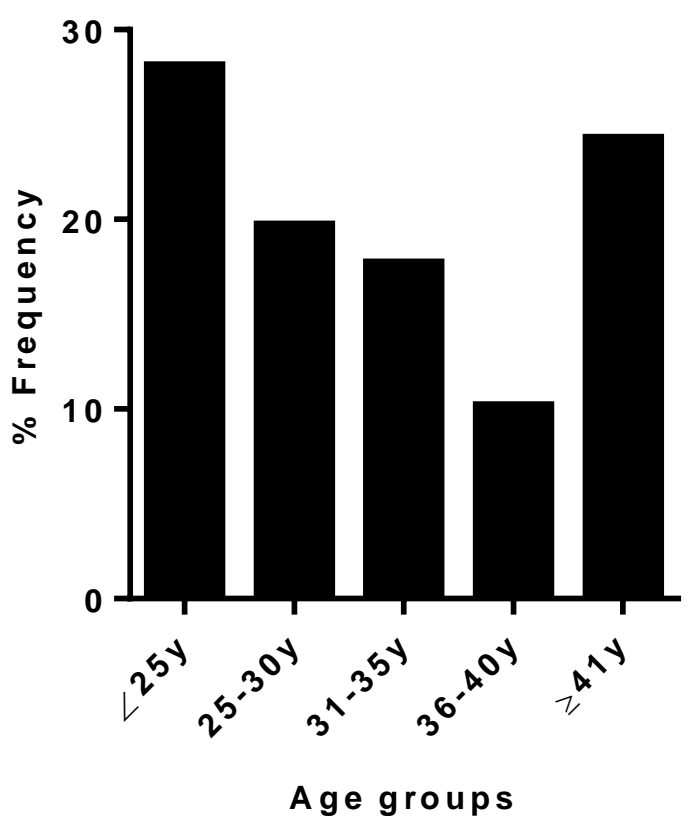

Figure 1. \% Frequency of HBV positive cases are classified according to age groups.

In figure 2, row factors and column factors were statistically significant $(* \mathrm{p}=0.0484$ and $* * * \mathrm{p}=0.0003$ respectively).

76.4\% HBeAg negative patients have highest HBV DNA copies per $\mathrm{ml}$ of blood samples.
Column factor analysis found very strong relationship between $\mathrm{HBeAg}$ negative and HbeAg positive cases, $\mathrm{p}$ value was $<0.0001$. The results are shown in figure 3 . 


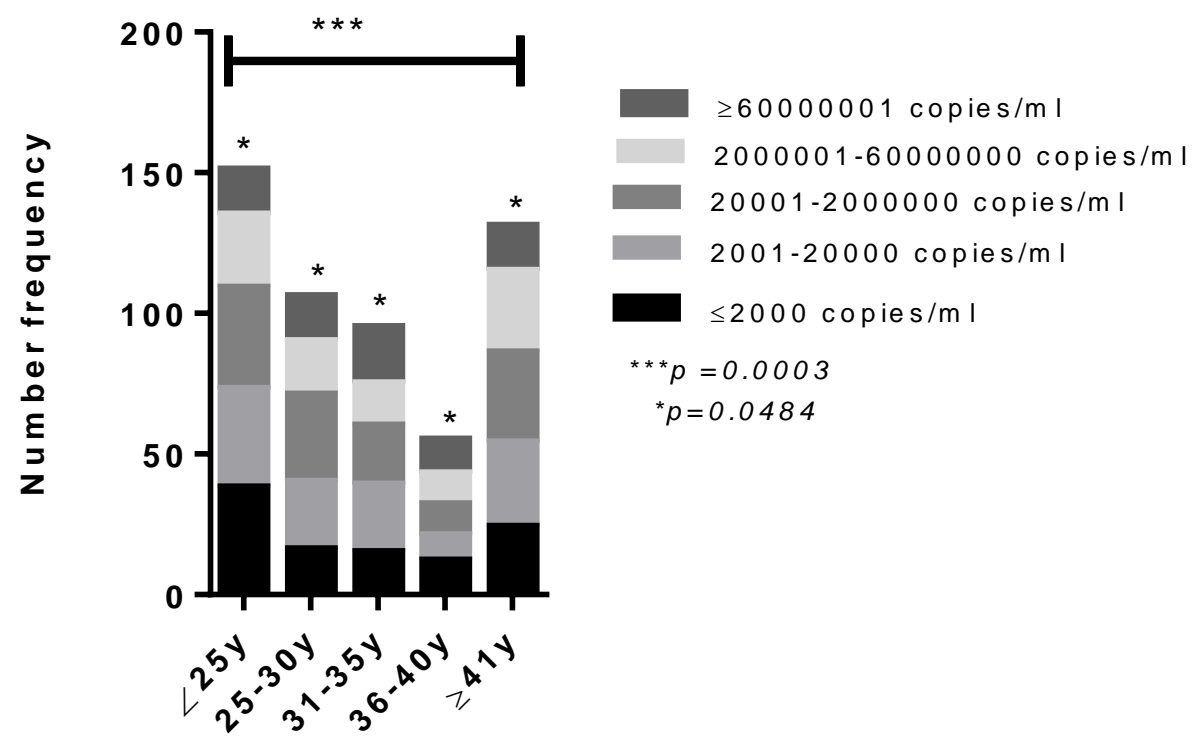

Age groups

Figure 2. Two-way ANOVA $(\alpha=0.05)$ analysis in age groups and HBV DNA groups of patients showed significant findings. Patients number and highest HBV DNA copies found in $<25 y$ age group.

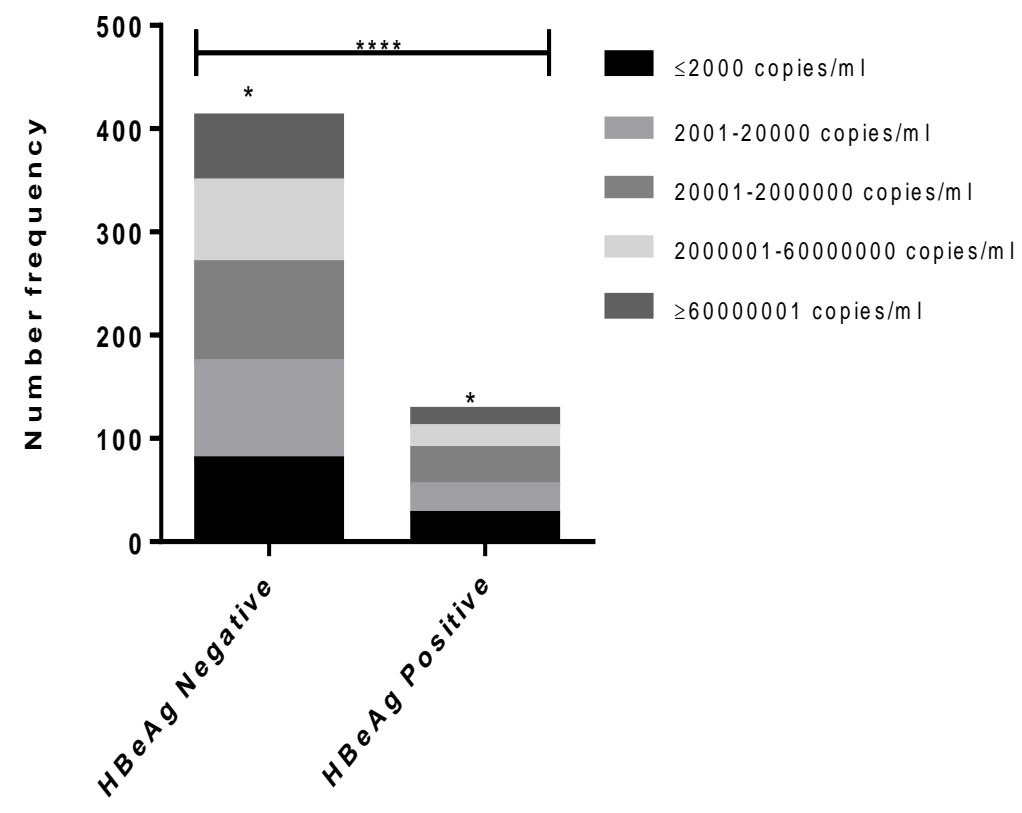

Figure 3. Patients are stratified with HBe antigen in association with HBV DNA copies $/ \mathrm{ml}$ of blood serum. The distribution of HBV DNA copies in two groups found significant by row and column factor analysis in Two-way ANOVA analysis. Figure 4 describe the frequency of respondents varies with different specifications. 

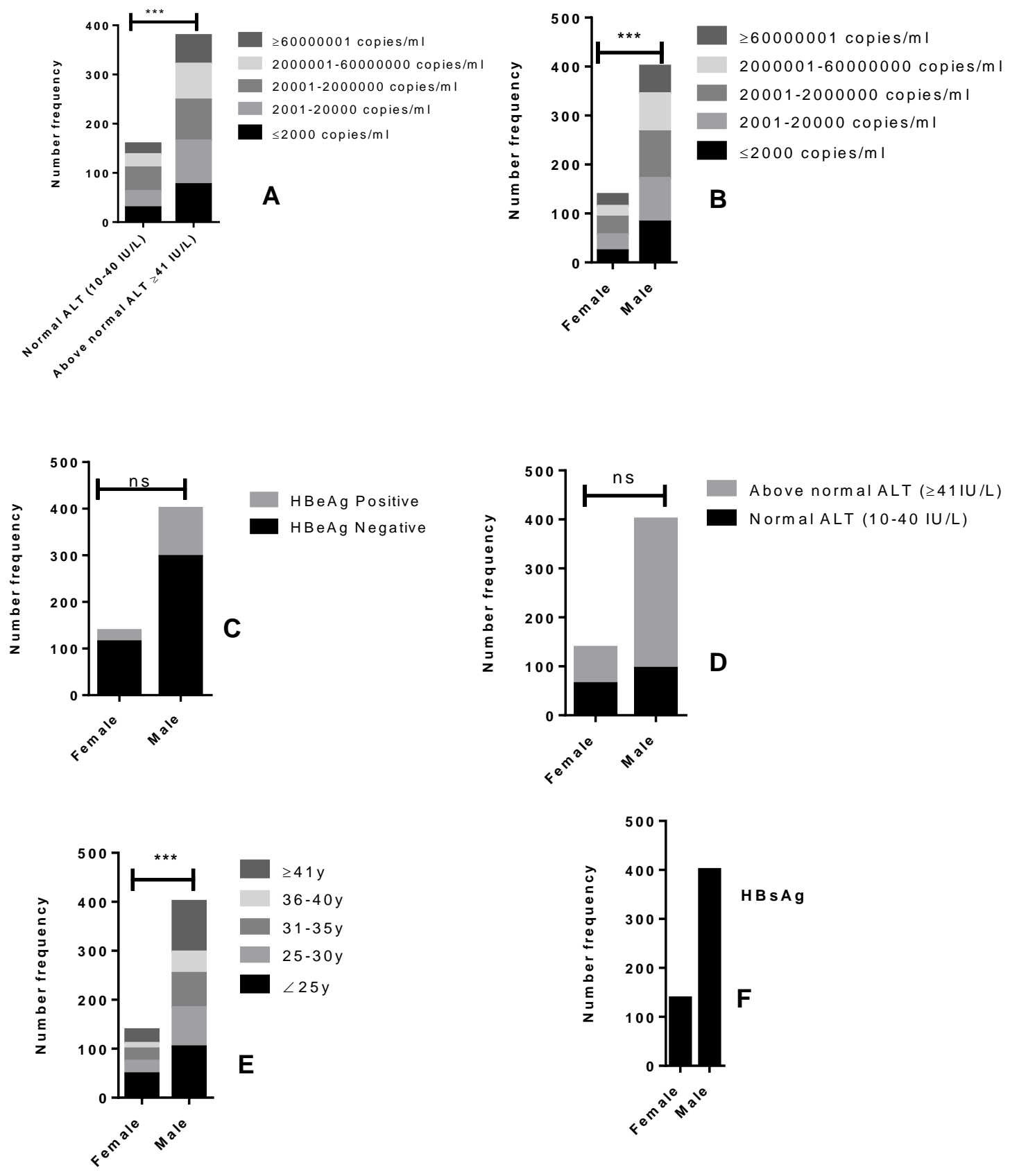

Figure 4. Number frequency of respondents varies with different specifications, [A] being with HBV DNA copies (ml) in ALT (IU/L), in [B] with gender, in [C] with gender and HBeAg positivity, in [D] with gender and ALT, in [E] with age and gender and in $[\mathrm{F}]$ with gender and $\mathrm{HBsAg}$.

In this study, hepatitis B viremia in hepatitis B surface antigenic patients was investigated and various conditions on sex, age, HbeAg (+/-) and serum ALT were also considered. Two age groups such as $<25 \mathrm{y}$ and $>40 \mathrm{y}$ were the dominant respondents in this study and male respondents were found highest frequency.

\section{Conclusions}

Bangladesh is a developing country with a population of 160 million. Like most advanced countries in Asia, significant increases have been accomplished for containment of different infectious diseases during last 30 years. Hepatitis 
$\mathrm{B}$ and Hepatitis $\mathrm{C}$ Virus infections remain a major health issue in end-stage renal disease (ESRD) population having important effect on overall morbidity as well as mortality. The chronic HBV infection can characteristically start with an acute infection, as indicated by the presence of $\mathrm{HBsAg}$ positivity for $\mathrm{HBeAg}$, a marker of ongoing viral replication, higher viral load and heightened infectivity may also develop and remain for months or years [27]. The age at acquiring of $\mathrm{HBV}$ has a large impact on the likelihood of the disease becoming chronic.

The presence of $\mathrm{HBeAg}$ in serum correlates with the presence of viral replication in the liver [29]. Monitoring ALT level is of value in assessing hepatocellular destruction in patients with chronic hepatitis B virus infection [29]. $\mathrm{HBeAg}$-positive patients with or without raised ALT level were found with active HBV virus replication (HBV DNA). This study does not agree with the other study's results [29] that many HBeAg-positive cases with normal ALT level were found infectious with detectable HBV DNA level. In contrast, two $\mathrm{HBeAg}$ positive patients had undetectable level of DNA. This might be the limitation of probe hybri-dization method. Though the probe hybridization assay allows measurement of viral load (quantitative detection), this method cannot measure a very small quantity of HBV DNA value $<0.5 \mathrm{pg} / \mathrm{ml}$. Traditionally sero-conversion of $\mathrm{HBeAg}$ to anti-HBe coincides with the decrease or normalization of serum ALT concentration and a very low level of HBV replication [30]. But some studies have concluded that presence or absence of $\mathrm{HBeAg} / \mathrm{anti}-\mathrm{HBe}$ may not necessarily reflect the serum HBV DNA concentration, particularly in persistent infection and thus absence of $\mathrm{HBeAg}$ and presence of anti$\mathrm{HBe}$ poorly correlates with complete loss of $\mathrm{HBV}$ DNA from the serum [31]. Further evaluation of $\mathrm{HBeAg}$ / anti-HBe assays by HBV DNA has been recommended in assessment of possible infectivity and chronic liver disease in the HBsAg positive patients [30]. The distribution of HBV DNA level was found significantly related in age groups $(p<0.05)$, gender group $(p<0.05)$, ALT group ( $\mathrm{p}<0.05)$, and HBeAg group $(\mathrm{p}<0.05)$. The HBV DNA level was documented to be significantly higher in the $\mathrm{HBeAg}$-positive group $(\mathrm{p}<0.05)$ in compared to the HBeAg-negative group.

\section{References}

1. Surrogate Testing of Donated Blood for nonA, non-B Hepatitis, and the discussion of the work of the Working Party on Transfusion Transmitted Hepatitis below.

2. Centers for Disease Control and Prevention. Recommendations for identification and public health management of persons with chronic hepatitis B virus infection. MMWR 2008; $57 \quad$ (No. $\quad$ RR08): http://cdc.gov/mmwr/preview/mmwrhtml/rr5 708a1.htm

3. Goldstein ST, Zhou F, Hadler SC, Bell BP, Mast EE, Margolis HS. A mathematical model to estimate global hepatitis B disease burden and vaccination impact. Int $\mathbf{J}$ Epidemiol 2005;34:1329-39. DOI: $10.1093 / \mathrm{ije} / \mathrm{dyi206}$

4. Mast EE, Ward JW. Hepatitis B vaccine. In: Plotkin SA, Orenstein WA, Offit PA, eds. Vaccines. 5th edition. Philadelphia, PA: Saunders; 2008.

5. CDC. A comprehensive immunization strategy to eliminate transmission of hepatitis B virus infection in the United States (US): recommendation of the Advisory Committee on Immunization Practices (ACIP). Part 1:

6. Lee WM. Hepatitis B virus infection. N Engl J Med 1997; 337: 1733-45. DOI: $10.1056 /$ NEJM199712113372406

7. Di Marco V, Lo lacono O, Gamma C, et al. The long-term course of chronic hepatitis B. Hepatology 1999; 30: 257-64. DOI: $10.1002 /$ hep.510300109

8. Mc Mahon BJ, Hoick P, Bulkow L, Snowball MM. Serologic and clinical outcomes of 1536 Alaska Natives chronically infected with hepatitis B virus. Ann Intern Med 2001; 135: 759-68.

DOI: $10.7326 / 0003-4819-135-9-200111060-$ $\underline{00006}$ 
9. Chu CM, Karayiannis P, Fowler MJ, et al. Natural history of chronic hepatitis B virus infection in Taiwan: studies of hepatitis B virus DNA in serum. Hepatology 1985; 5: 431-34.

DOI: $10.1002 /$ hep. 1840050315

10. Manno M, Cammá C, Schepis F, Bassi F, Gelmini R, Giannini F, et al. Natural history of chronic HBV carriers in Northern Italy: morbidity and mortality after 30 years. Gastroenterology.2004;127:756-63.

DOI: 10.1053/j.gastro.2004.06.021

11. Fattovich G. Natural history of hepatitis B. J Hepatol. 2003;39:S50-8.

DOI: $10.1016 / \mathrm{S} 0168-8278(03) 00139-9$

12. Sarat CM. Chronic hepatitis B: East meets west.http://www.hepb.org/pdf/misraabstract6 02.pdf.Date:01.12.2007.

13. World Health Organization Global distribution of hepatitis A, B and C, 2001. Weekly Epidemiol Rec. 2002; 77: 45-47.

14. Fattovich G, Bortolotti F, Donato F. Natural history of chronic hepatitis $\mathrm{B}$ : special emphasis on disease progression and prognostic factors. J Hepatol. 2008;48:33552.

DOI: 10.1016/j.jhep.2007.11.011

15. Hussain AB, Karamat KA, Anwar M, Kazmi SY, Tariq WU. Correlation of HBV DNA PCR and HBeAg in hepatitis carriers.J Coll Physicians Surg Pak. 2004; 14: 18-20.

16. Badur S, Akgun A. Diagnosis of hepatitis B infections and monitoring of treatment. J ClinVirol.2001; 21: 229-37. DOI: $10.1016 / \mathrm{s} 1386-6532(01) 00147-0$

17. Ljunggren KK, Nordenfelt E, Kidd A. Correlation of $\mathrm{HBeAg} /$ anti-HBe, ALT levels and HBV DNA PCR results in HBsAgpositive patients.J Med Virol.1993; 39: 297302.

DOI: $10.1002 / \mathrm{jmv} .1890390408$

18. Alagiozian-Angelova V, Alagiozian D, Antonov K, Kruslev Z. Clinical significance of serum HBeAg and HBV DNA specific values of virus replication in chronic hepatitis B virus infection. Folia Med. 1998;
40: 34-41.

19. Smith HM, Lau JY, Davies SE, Daniels HM, Alexander GJ, Williams R. Significance of serum IgM anti-HBc in chronic hepatitis B virus infection. J Med Virol.1992; 36:16-20. DOI: $10.1002 / j m v .1890360104$

20. Berninger M, Hammer M, Hoyer B, Gerin JL. An assay for the detection of the DNA genome of hepatitis B virus in serum.J Med Virol.1982; 9 9: 57-68. DOI: $10.1002 / j m v .1890090109$

21. Kaplan PM, Gerin JL, Alter HJ. Hepatitis Bspecific DNA polymerase activity during post-transfusion hepatitis.Nature 1974; 249: 762-63.

DOI: $10.1038 / 249762 \mathrm{a} 0$

22. Norden H, Brattstorm C, Magnius L. High frequency of hepatitis B virus DNA in anti$\mathrm{HBe}$ positive sera on longitudinal follow up of the patients with renal transplants with chronic hepatitis Br J Med Virol. 1989; 27: 322-28.

DOI: $10.1002 / j m v .1890270412$

23. Dienes HP, Gerken G, Goeagen B, Heermann K, Gerlich W, Meyer ZumBuschenfelde KH. Analysis of precore DNA sequence and detection of precore antigen in liver specimens from patients with anti-hepatitis B e positive chronic hepatitis.Hepatology 1995; 21: 1-7.

24. Carman WF, Jacyna MR, Hadziyannis S, Karayiannis P, McGarvey MJ, Makris A, Thomas HC. Mutation preventing formation of hepatitis $\mathrm{B}$ e antigen in patients with chronic hepatitis B infection.Lancet 1989; 2: 588-91.

DOI: $10.1016 / \mathrm{S} 0140-6736(89) 90713-7$

25. Fiordalisi G, Ghiotto F, Castelnuovo F, Primi D, Cariani E. Analysis of the hepatitis B virus genome and immune response in HBsAg, anti-HBs positive chronic hepatitis. J Hepatol.1994; 20: 487-93. DOI: $10.1016 / \mathrm{S} 0168-8278(05) 80495-7$

26. Miyakawa Y, Okamoto H, Nayumi M. The molecular basis of hepatitis $\mathrm{B}$ e antigen (HBeAg)-negative infections.J Viral 
Hepat.1997;

4:

DOI: 10.1046/j.1365-2893.1997.00101.x

27. Dr. Nazia Haque, M Phil (Microbiology), Medical Officer, Dept.of Microbiology, MMC, Mymensingh

28. Badur S, Akgun A. Diagnosis of hepatitis B infections and monitoring of treatment. J Clin Virol. 2001; 21: 229-37. DOI: $10.1016 / \mathrm{S} 1386-6532(01) 00147-0$

29. Hussain AB, Karamat KA, Anwar M, Kazmi SY, Tariq WU. Correlation of HBV DNA PCR and HBeAg in hepatitis carriers. J Coll Physicians Surg Pak. 2004; 14: 18-20.

30. Alagiozian-Angelova V, Alagiozian D,
Antonov K, Kruslev Z. Clinical significance of serum HBeAg and HBV DNA specific values of virus replication in chronic hepatitis B virus infection. Folia Med. 1998; 40: 34-41.

31. Luo KX, Zhou R, Liang ZS, Jiang S. Correlation between the prevalence of serum HBV-DNA and immunoserologic HBV markers in the subjects with or without hepatitis. Immunol Invest. 1992; 21: 275-81. DOI: $10.3109 / 08820139209072264$ 